Jana Kliestikova,

JUDr., PhD., Lecturer of the Department of Economics, Faculty of Operation and Economics of Transport and Communications, University of Zilina (Zilina, Slovakia);

Katarina Janoskova,

$P h D$, Lecturer of the Department of Economics,

Faculty of Operation and Economics of Transport and Communications, University of Zilina (Zilina, Slovakia)

\title{
BRANDING WITH UNDERSTANDING: HOW NATIONAL PROFILE OF CONSUMER INFLUENCES BRAND VALUE PERCEPTION ${ }^{1}$
}

Practice has shown that inappropriate branding pattern can be branding pattern which was previously very appropriate on other market or for other brand. By application of cluster analysis in OECD' countries, in the context of Hofstede model of social dimensions, we found that the cause of this phenomenon is the significance of the impact of the national socio-cultural profile of consumers in the subjective perception of the brand value. On the example of Slovak Republic was confirmed that customers perceive as more valuable the brands, which socialcultural profile of the country of origin is convergent with the national. Subsequently, we identified individual attributes of the socio-cultural profile with the sources of individually perceived the brand value.

Keywords: brand, branding, brand value, consumer national profile, Hofstede cultural dimensions, Slovak Republic, OECD countries.

DOI: 10.21272/mmi.2017.3-14

Introduction. Nowadays, when market environment is more and more globalized, brand value building and managing is a significant challenge for managers. The problem is not only in the choice of appropriate metrics of brand value quantification but also in the choice of appropriate branding strategies. The reason is the existence of many theoretical approaches to this issue and also the existence of many differences between them. Based on these differences, managers often choose inappropriate branding pattern and then undermining the brand value.

The brand value, which is subjectively perceived by customers, represents the valuable source of competitive advantage [17]. For the brand value building and managing exists many theoretical approaches, which according to Krizanova et al [9] create many problems in application practice. They differ from each other in the approach to measuring the brand value, as well as in the strategy of building and managing of the brand value. Chang \& Chung [6] also state these facts. Pappu et al. [14] recommended take into account social-cultural country profile where we try to apply branding concept and also social-cultural country profile where was created this concept. Thanks to these recommendations we avoid to undesirable impacts, which are associated with inappropriate implementation or with implementation of inappropriate branding pattern. However according to Voyer et al. [20] in the literature there is lack of an explanations of individual social-cultural customers' characteristics, in the context of the brand value sources which are perceived by them. This fact competitively disqualifies 1) foreign brands which are entering on the domestic market; 2) domestic brands which exist in the domestic competitive environment. Actual exit of Marks \& Spencer' brand from the Slovak market is example of the competitive disadvantage of foreign brands. Another example is the Slovak failure of KFC, which is one of the hundred most valuable brands in the world according to

${ }^{1}$ The research leading to these results has received funding from the project titled "Integrated model of management support for building and managing the brand value in the specific conditions of the Slovak Republic" in the frame of the program of Slovak Research and Development Agency under the grant agreement number APVV-15-0505. 
Interbrand.

Krizanova et al. [10] state that disrespect of own social-cultural specifics could lead to the adverse spiral effect, in the case of original Slovak brands. Spiral effect has following behavior: domestic brands apply inappropriate patterns of branding; the brand value does not record another rise or it fall down managers prefer to stop activities of building and managing the brand value - domestics brands are losing their competitive potential in comparison with foreign brands - market deforms - on the market only stay strong foreign brands which use their original concept of building and managing of their values - impression of "good practice" is created - managers of domestics brands apply foreign patterns and the cycle is repeated. Scientific literature reflects the need of respects the socio-cultural country profile, but in case of solution of this phenomena it is not enough [19]. This phenomenon creates a space for identify 1) convergences and divergences of individual socio-cultural country profiles and 2) causal correlations between attributes of socio-cultural profiles and subjective perceived sources of the brand value.

Hsu et al. [4] indicate, in terms of usability in economic sciences, Hofstede model of socio-cultural dimensions, which was created in the 80 s of the 20th century as the most appropriate sociological model of cultural specifics. Basnakova et al. [1] verified reliability and validity of this model in the context of current societal changes. This model defines the socio-cultural country profiles through six basic attributes, which are:

- power distance;

- individualism;

- masculinity;

- uncertainty avoidance;

- long term orientation and

- indulgence.

Mazanec et al. [13] state, with using this model, existence of impact of socio-cultural profile of customers on their buying behavior. Hur et al. [5] state the impact of national specifics on perception of the brand value with using of this model. However, their findings have only general nature and they do not pay attention to the issue of detecting the degree of influence of individual attributes of socio-cultural profile to the brand value.

Methods. This study uses primary data as well as secondary data from the methodology approach. Secondary data are the values of socio-cultural countries profiles by Geert Hofstede [3] and the ratings of the most valuable brands in 2015 in the Slovak Republic (Superbrands score [16]) and worldwide (the rating of Interbrand [7]). Basic method for processing of secondary data is cluster analysis. Pilling [15] states that objective of this analysis is placed the objects into the groups with condition that two objects from the one cluster were more similar each other than two objects from different cluster.

According to Trindade et al. [18] the cluster analysis consists of following steps 1) selection of input database; 2) selection of parameters; 3) name of the object; 4) choice of clustering technique; 5) choice of using distance; 6) placing in clusters; 7) choice of distances in Dendrogram; 8) selection of appropriate techniques for creation of Dendrogram; 9) an explanation of the best Dendrogram similarities of objects and variables. Input for clustering in terms of data analysis is data matrix. Data matrix contains variables (in our case the attributes of the socio-cultural profile) in $m$ columns and $n$ rows (in our case OECD countries) on which these characters are measured. Every object it means the row of data matrix (1), that is, xiT $=(x i, 1, \ldots x i, j, \ldots x i, m)$ is characterized by its characteristics [8].

Table 1 provides a basic set of data which we need for realizing the cluster analysis of socio-cultural profiles OECD countries; this table is consist of: PD is power distance; I is individualism; $M$ is masculinity; UA is uncertainty avoidance; LTO is long term orientation and I is indulgence.

As it is shown in table 1, the spread of scores is significant. Power distance oscillates between 11 (Austria) and 100 (Slovak Republic), individualism between 18 (Korea) and 91 (United States), 
masculinity between 5 (Sweden) and 100 (Slovak Republic), uncertainty avoidance between 23 (Denmark) and 100 (Greece), long term orientation between 21 (Australia) and 100 (Korea) and indulgence between 0 (Israel) and 97 (Mexico). It verifies the theory based on rejection of uniform brand value building and managing models. When smaller supranational entities are analyzed - such a V4 for example, the results are also interesting - Czech Republic, Hungary, Poland and Slovak Republic are comparable only in scope of indulgence, in all other dimensions of socio cultural profiles are notable divergences in score quantification from 28 (individualism) to 54 (power distance).

Table 1 - Set of data used for cluster analysis (developed by the author based on [3])

\begin{tabular}{|l|l|l|l|l|l|l|}
\hline \multicolumn{1}{|c|}{$\begin{array}{c}\text { Variables I } \\
\text { Observations }\end{array}$} & PD score & I score & M score & UA score & LTO score & I score \\
\hline Australia & 36 & 90 & 61 & 51 & 21 & 71 \\
\hline Austria & 11 & 55 & 79 & 70 & 60 & 63 \\
\hline Belgium & 65 & 75 & 54 & 94 & 82 & 57 \\
\hline Canada & 39 & 80 & 52 & 48 & 36 & 68 \\
\hline Chile & 63 & 23 & 28 & 86 & 31 & 68 \\
\hline Czech Republic & 57 & 58 & 57 & 74 & 70 & 29 \\
\hline Denmark & 18 & 74 & 16 & 23 & 35 & 70 \\
\hline Estonia & 40 & 60 & 30 & 60 & 82 & 16 \\
\hline Finland & 33 & 63 & 26 & 59 & 38 & 57 \\
\hline France & 68 & 71 & 43 & 86 & 63 & 48 \\
\hline Germany & 35 & 67 & 66 & 65 & 83 & 40 \\
\hline Greece & 60 & 35 & 57 & 100 & 45 & 50 \\
\hline Hungary & 46 & 80 & 88 & 82 & 58 & 31 \\
\hline Iceland & 30 & 60 & 10 & 50 & 28 & 67 \\
\hline Ireland & 28 & 70 & 68 & 35 & 24 & 65 \\
\hline Israel & 13 & 54 & 47 & 81 & 38 & 0 \\
\hline Italy & 50 & 76 & 70 & 75 & 61 & 30 \\
\hline Japan & 54 & 46 & 95 & 92 & 88 & 42 \\
\hline Korea & 60 & 18 & 39 & 85 & 100 & 29 \\
\hline Latvia & 44 & 70 & 9 & 63 & 69 & 13 \\
\hline Luxembourg & 40 & 60 & 50 & 70 & 64 & 56 \\
\hline Mexico & 81 & 30 & 69 & 82 & 24 & 97 \\
\hline Netherlands & 38 & 80 & 14 & 53 & 67 & 68 \\
\hline New Zealand & 22 & 79 & 58 & 49 & 33 & 75 \\
\hline Norway & 31 & 69 & 8 & 50 & 35 & 55 \\
\hline Poland & 68 & 60 & 64 & 93 & 38 & 29 \\
\hline Portugal & 63 & 27 & 31 & 99 & 28 & 33 \\
\hline Slovak Republic & 100 & 52 & 100 & 51 & 77 & 28 \\
\hline Slovenia & 71 & 27 & 19 & 88 & 49 & 48 \\
\hline Spain & 57 & 51 & 42 & 86 & 48 & 44 \\
\hline Sweden & 31 & 71 & 5 & 29 & 53 & 78 \\
\hline Switzerland & 34 & 68 & 70 & 58 & 74 & 66 \\
\hline Turkey & 66 & 37 & 45 & 85 & 46 & 49 \\
\hline United Kingdom & 35 & 89 & 66 & 35 & 51 & 69 \\
\hline United States & 40 & 91 & 62 & 46 & 26 & 68 \\
\hline & & & & & \\
\hline
\end{tabular}

This result indicates that branding methods, models and concepts should be applied in different ways although these countries are stereotypically perceived as similar when their national profiles are discussed - all are former socialistic countries in a similar region (central Europe) with comparable macroeconomic indicators evolution and in addition - three of these four countries are formed by Slavic population. So, stereotypically for example Slovak Republic should be more convergent with Czech 
Я. Кльестікова, К. Яноскова. Брендинг з розумінням: як національний профіль споживача впливає на сприйняття цінності бренду

Republic (both Slavic with common socio-political history during 20th century) than with Hungary (effort to Hungarians the Slovak population in 19th century and different ethnicity). But the results are a bit of different - Slovak Republic and Czech Republic are really mostly convergent (the exception is only masculinity dimension, where Hungarian and Slovak profiles are more convergent than Czech and Slovak), but in fact, Czech Republic is indifferent when its convergence with Hungary and Slovak Republic is analyzed (individualism, long term orientation and indulgence are more convergent between Czech Republic and Slovak Republic while power distance, masculinity and uncertainty avoidance are more convergent between Czech Republic and Hungary). As a clustering method we used "nearest neighbor method" which is based on the minimum distance. It is that this method finds two objects which are separated by the shortest distance and placed them into the cluster. Another cluster is formed by adding a third nearest neighbor. This process is repeated until all objects are in a common cluster. The distance between two clusters is defined as the shortest distance of any point in the cluster to any point in another cluster. Based on the results of cluster analysis we are able to explain the occurrence of brands in the position most valuable brands according to Slovak consumers (secondary data from rating Superbrands 2015). We expect that this position will contain brands which are from the countries with higher degree of convergence of attributes of their socio-cultural profiles in relation to the Slovak Republic. According to the representation of the quartile correlation of the values of attributes sociocultural profile of the Slovak Republic and the countries of origin of most valuable brands by Superbrands 2015. Then it is possible to sort individual attributes according to their importance and assign to them an equivalent source of the brand value according to Filieri and Lin [2]. These authors defined six basic pillars for building and managing the brand value:

- price;

- symbolic meaning;

- social visibility;

- time commitment;

- potential for harm and

- technical complexity.

Table 2 - Relationship between attributes of socio-cultural profile and the source of the brand value (own study)

\begin{tabular}{|l|l|l|}
\hline Attribute of socio-cultural profile & Attribute of brand value perception & Character of relationship \\
\hline Power distance & Price & Direct proportion \\
\hline Individualism & Symbolic meaning & Undirect proportion \\
\hline Masculinity & Social visibility & Direct proportion \\
\hline Uncertainty avoidance & Potential for harm & Direct proportion \\
\hline Long term orientation & Time commitment & Direct proportion \\
\hline Indulgence & Technical complexity & Direct proportion \\
\hline
\end{tabular}

Results and discussion. Thanks to the realization of cluster analysis of OECD countries, in the context of their socio-cultural profiles formulated by Geert Hofstede, we found that they create six internally homogeneous and externally heterogeneous groups with various degrees of inter-group divergence and convergence (see Fig. 1).

OECD countries are grouped in the cluster based on their socio-cultural similarities. This distribution is following: cluster 1: Australia, Canada, Ireland, New Zealand, United Kingdom, United States; cluster 2: Austria, Belgium, Czech Republic, France, Germany, Hungary, Italy, Japan, Luxembourg, Switzerland; cluster 3: Chile, Greece, Mexico, Poland, Portugal, Slovenia, Spain, Turkey; cluster 4: Estonia, Israel, Korea, Latvia; cluster 5: Denmark, Finland, Iceland, Netherlands, Norway, Sweden; cluster 6: Slovak Republic. 


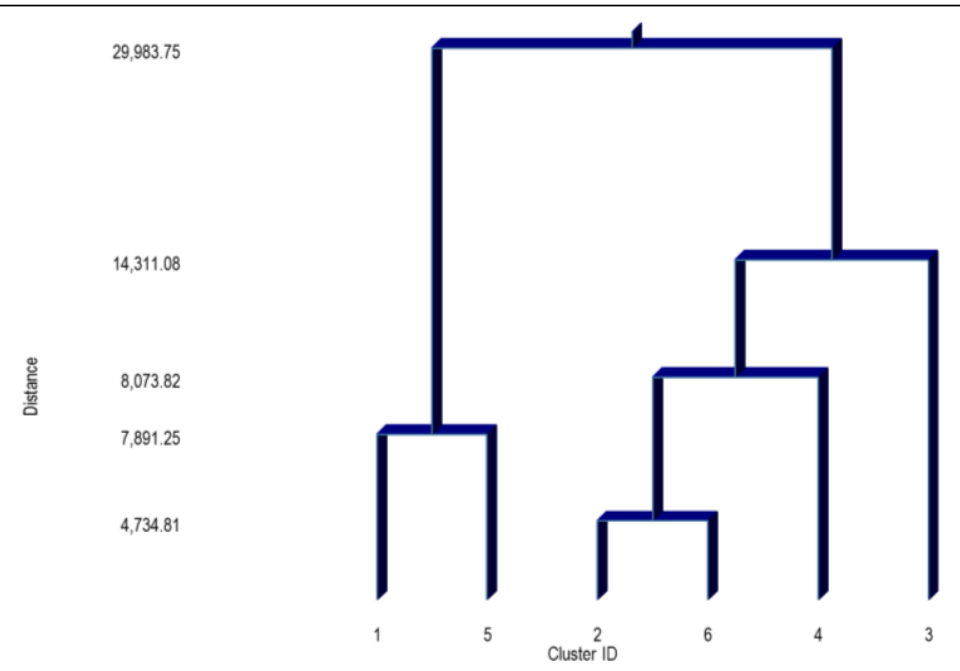

Figure 1 - Cluster Dendrogram of OECD countries based on their socio-cultural profiles (own study)

We can state that despite the general diversity of analysed OECD countries socio-cultural profiles, the greatest degree of convergence is between clusters 2 and 6 . So, the greatest degree of inter-group similarity occurs between Slovak Republic on the one hand and Austria, Belgium, Czech Republic, France, Germany, Hungary, Italy, Japan, Luxembourg, Switzerland on the other hand. It means that brand value building and managing concepts effective on the markets of countries grouped in cluster 2 could be applied without significant changes on the Slovak market and vice versa. This is caused by the proximity of these clusters when the prospective of vertical axis is taking into account. On the contrary, the greatest degree of divergence is between these clusters (2 and 6) and cluster 3 where Chile, Greece, Mexico, Poland, Portugal, Slovenia, Spain, Turkey were clustered Thanks to the interpretation of Dendrogram we can also say, that clusters 2 and 6 are more convergent with clusters 1 and 5 as with cluster 4 .

While grouping of some countries into the cluster could be considered to be unambiguous in relative to their ethno-cultural characteristics (Austria, Germany, Switzerland), cluster analysis also found surprising results. The most surprising was, that despite the fact that Slovak Republic and Czech Republic have common socio-cultural past thanks to the existence of the former Czechoslovak Federal Republic, they were grouped into the different clusters. This finding is essential for the practice of foreign companies which divide markets into bigger regional entities and centralize their management. It is generally known that markets of contemporary Slovak Republic and Czech Republic are perceived as still uniform market of former Czechoslovakia. This is an example of incorrect demolition of state borders and creation of supranational market environment without taking into account national specific.

On the other hand, inclusion of Slovak Republic and Czech Republic into the different clusters we can derive from greater similarity of socio-cultural profiles of Czech Republic with Austria which is caused by longer common historical development of these countries under the Austro-Hungarian Empire. This situation is also explained by convergence between clusters 6 (Slovak Republic) and cluster 2 (Austria, Czech Republic and Hungary as the other successor republics of this ex monarchy). The fact that the Slovak Republic is in a separate cluster indicates uniqueness of the socio-cultural profile of its citizens as potential consumers when OECD countries benchmarking is discussed in this context. Based on these facts we can say that Slovak consumers should perceived Slovak brands more valuable in comparison with foreign brands, as in our original assumption. Table 3 shows comparison of yarrow of the most valuable 
Я. Кльестікова, К. Яноскова. Брендинг з розумінням: як національний профіль споживача впливає на сприйняття цінності бренду

Slovak brands (according to the Superbrands) and the most valuable brands of the world (according to the Interbrand) in 2015. Both ratings were primarily created based on the subjective perception the brand value by customers and this fact allows their use for the needs of our study.

Table 3 - Comparison of the occurrence of countries of origin of the most valuable brands (own study)

\begin{tabular}{|l|r|r|r|r|}
\hline \multicolumn{1}{|c|}{ Country } & Superbrands [brands] & Interbrand [brands] & Superbrands [\% of brands] & Interbrand [\% of brands] \\
\hline Austria & 2 & 0 & 6,06 & 0,00 \\
\hline Canada & 2 & 1 & 6,06 & 1,25 \\
\hline Czech Republic & 5 & 0 & 15,15 & 0,00 \\
\hline France & 1 & 7 & 3,03 & 8,75 \\
\hline Germany & 4 & 10 & 12,12 & 12,50 \\
\hline Poland & 1 & 0 & 3,03 & 0,00 \\
\hline Slovak Republic & 15 & 0 & 45,45 & 0,00 \\
\hline Switzerland & 1 & 2 & 3,03 & 2,50 \\
\hline United Kingdom & 1 & 6 & 3,03 & 7,50 \\
\hline USA & 1 & 54 & 3,03 & 67,50 \\
\hline
\end{tabular}

According to Slovak customers are the most valuable Slovak brands (position of Slovak Republic in the cluster 6 ) as well as representation of brands from countries which are grouped in the cluster 2 (2 from Austria, 1 from France, 4 from Germany and 1 from Switzerland). These facts confirm our original assumption that socio-cultural country profile has impact on the subjectively perceived the brand value. According to Slovak customers in the rating of the most valuable brands are also grouped 2 Canadian brands, 1 British brands and 1 American brand. Countries of origin of these brands are grouped in cluster 1 , which is the nearest to the clusters 2 and 6 from the point of view their socio-cultural profiles. There is also one representative of cluster 3 - Poland. Figure 2 shows graphical representation the degree of similarity of socio-cultural profiles origin countries of the most valuable brands by Superbrands in 2015 .

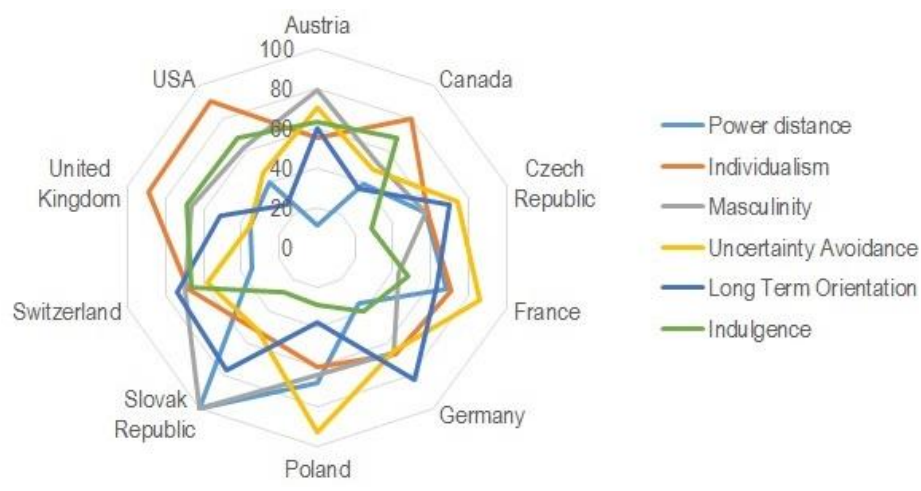

Figure 2 - Radar chart of socio-cultural profiles of selected countries (own study)

The same degree of convergence as in relation to clusters 2 and 6 was detected at the level of cluster 5 . However, no brands which are grouped in this cluster are not in this rating. This finding is important because it allows identifying attributes of socio-cultural profiles which do not have impact on the subjectively perceived the brand value from the view of Slovak customers. These are the attributes of individualism and uncertainty avoidance, in which cluster 5 was convergent to the cluster 6 from the point of view quartile characteristic of analysis sample. However, despite of this fact, brands which are coming from countries which are grouped in the cluster 5 were not identified as valuable by Slovak customers in Suberbrands in 2015. Figure number 3 
shows graphical representation of degree of similarity of individual socio-cultural countries profiles which are grouped in cluster 5 and Slovak Republic.

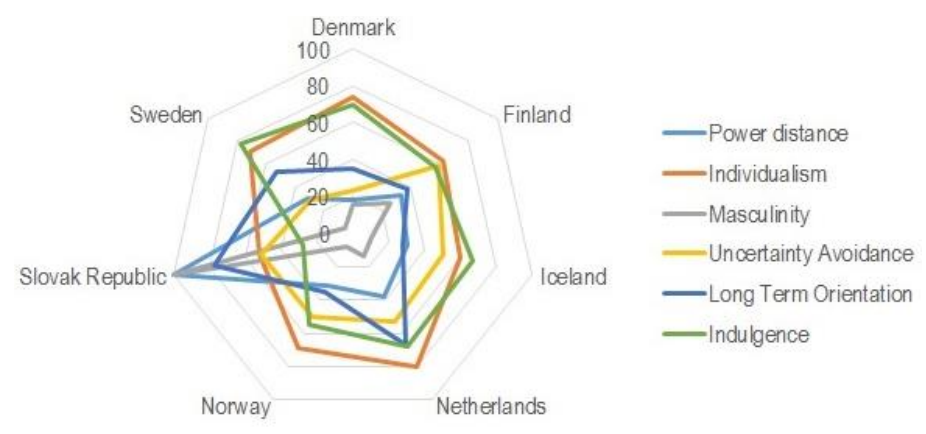

Figure 3 - Radar chart of socio-cultural countries profiles (cluster 5 / Slovak Republic) (own study)

Based on these facts we can say that exist some attributes which have impact on the subjective brand value perceived by Slovak consumer, namely: power distance; masculinity; long term orientation and indulgence.

If we want to use these facts in both theory and practice of branding it is necessary to work with attributes according to the two steps: rank them according to their importance; assigned them to the specify source of the brand value.

Rank of attributes according to their importance stems from the frequency of quartile correlation socio-cultural profiles of Slovak Republic and socio-cultural profiles origin countries of the most valuable brands by Superbrands. This situation we can see in the table 4 where: PD is power distance; $M$ is masculinity; LTO is long term orientation and I is indulgence.

Table 4 - Comparison of the occurrence of countries of origin of the most valuable brands (own study)

\begin{tabular}{|l|l|l|c|c|}
\hline & PD & M & LTO & I \\
\hline Austria & & & & \\
\hline Canada & & & $X$ & $X$ \\
\hline Czech Republic & & & $X$ & \\
\hline France & $X$ & $X$ & $X$ & \\
\hline Germany & & & & \\
\hline Switzerland & & & & \\
\hline United Kingdom & & & & \\
\hline United States & & & & \\
\hline
\end{tabular}

According to table 4 the greatest impact on the subjective perceived of the brand value has attribute long term orientation. On the second place there are masculinity, power distance and indolence. At the last position there are attributes with the lowest impact.

Filieri and Lin [2] provide the concept of sources of the brand value. According to their conclusions we can say that based on the identified rank of the impact of attributes of socio-cultural country profile of origin brand, the ranking of sources of the brand value from the point of view of Slovak consumers is following: 1) time commitment; 2) social visibility; 3) price and technical complexity. Symbolic meaning and potential for harm do not have sufficient value creation potential in specific condition of Slovak Republic, vice versa.

With respect to specific of Slovak Republic we can state that building and managing the brand value 
could be based on the quality of product (time commitment), social visibility, and technical complexity of product. In the process of determining the optimal price level exist the relation between it and subjectively perceived brand value. When the price level grows, subjectively perceived brand value grows too. However, this rule is true only to certain "breaking point". When the price exceeds this point then subjectively perceived the brand value is reduced.

Lizbetinova and Weberova [11,12] created the study in which they realized questionnaire survey on the market of Slovak Republic and Czech Republic. Based on it, they stated the need of return from the approaches which are based on the quality as a source of the brand value to the image-oriented approaches.

However, our conclusions refute their study. It means that Slovak customer is from the psychological point of view still conservative with strong tendencies to the historical socio-political heritage and although accelerating globalization and related processes and phenomena although he is not aware of it. This postulate is proven by practice of foreign and domestic brands applying either their original branding patterns or patterns copied from foreign effective practice of brand value building and managing what leads to opposite effect - undesirable decline in brand value.

Conclusion. The brand value is "powerful weapon" for marketing managers that can easily turn against to them. This argument is demonstrated in practice of brands which entered on the foreign markets and then applied the branding concepts which previously were effective, but this concept paradoxically irreversibly damaged their brand value. This process is also typical for brands operating on national markets, which applied branding concepts recommended by theory of branding concepts or they applied branding concepts which were applied by competitors. These decisions caused those products which were placed on the market under these brands quickly ending their life cycles. Thanks to our study we can provide following results - this currently more frequently occurring phenomenon is in accordance with disrespect of specific market environment in which the brand operates. On example of Slovak Republic, we proved that consumers perceived as more valuable brands, whose socio-cultural profile or origin country is convergent with national. In this study we used the secondary data and cluster analysis of OECD countries, in the context of sociocultural profiles which were created by Geert Hofstede. Based on the data and methodology we identified specific attributes of socio-cultural profiles with direct impact on the subjectively perceived brand value by customers. We concluded that in the conditions of Slovak Republic exist these attributes: long term orientation, masculinity, power distance and indolence. Thanks to the converting mentioned attributes on specific source of the brand value, we state that from the point of view of Slovak consumers the key sources of the brand value are these: time commitment, social visibility, price and technical complexity. We consider these findings are key from the view of future effective existence of brands on Slovak market with implications for international effect of brands. We also believe, they create a platform for future direction of research in the area of impact of national specifics to creating new ways of building and managing the brand value in a globalized market environment.

1. Basnakova, J., Brezina, I., \& Masaryk, R. (2016). Dimensions of culture: the case of Slovakia as an outlier in Hofstede's research. Ceskoslovenska Psychologie, 60 (1), 13-25.

2. Filieri, R., \& Lin, Z.B., (2017). The role of aesthetic, cultural, utilitarian and branding factors in young Chinese consumers' repurchase intention of smartphone brands. Computers in Human Behavior, 67, 139-150.

3. Geert Hofstede Dimensions of National Culture (2017). geert-hofstede.com. Retrieved from https://geerthofstede.com/national-culture.html.

4. Hsu, S.Y., Woodside, A.G., \& Marshall, R., (2013), Critical Tests of Multiple Theories of Cultures' Consequences: Comparing the Usefulness of Models by Hofstede, Inglehart and Baker, Schwartz, Steenkamp, as well as GDP and Distance for Explaining Overseas Tourism Behavior. Journal of Travel Research, 52 (6), 679-704.

5. Hur, W.M., Kang, S., \& Kim, M. (2015). The moderating role of Hofstede's cultural dimensions in the customer-brand relationship in China and India. Cross Cultural Management-an International Journal, 22 (3), 487-508.

6. Chang, W.J., \& Chung, Y.C., (2016), A review of brand research (1990-2010): classification, application and development trajectory. International Journal of Services Technology and Management, 22 (1-2), 74-105.

7. Interbrand (2017). interbrand.com. Retrieved from http://interbrand.com/best-brands/best-global-brands/2015/ranking/. 
8. Kliestik, T., \& Kral, P., (2011). Cluster analysis in corporate governance. Ekonomicko-manazerske spektrum, 5 (2), 91-96.

9. Krizanova, A., Masarova, G., Stefanikova, L., \& Rypakova, M. (2015). Building a Brand in the Context of Sustainable Development. In: proceedings of International Conference on Management Engineering and Management Innovation (pp. 79-84). PRC: Changsha.

10. Krizanova, A., Masarova, G., \& Stefanikova, L. (2014). The Importance of Brand Management in the Automotive Industry in the Slovak Market. In: proceedings of 2nd International Conference on Management Innovation and Business Innovation (pp. 23-28). Thailand: Bangkok.

11. Lizbetinova, L., \& Weberova, D. (2016a). Managing Attitudes of Consumers towards Brands and Quality. In: proceedings of 27th International Business Information Management Association Conference. Italy: Milan.

12. Lizbetinova, L., \& Weberova, D. (2016b). Consumer Attitudes towards Brands in Relation to Price. In: proceedings of 27th International Business Information Management Association Conference (1850-1859). Italy: Milan.

13. Mazanec, J.A., Crotts, J.C., Gursoy, D., \& Lu, L. (2015). Homogeneity versus heterogeneity of cultural values: An itemresponse theoretical approach applying Hofstede's cultural dimensions in a single nation. Tourism Management, 48, 299-304.

14. Pappu, R., Quester, P.G., \& Cooksey, R.W. (2006). Consumer-based brand equity and country-of-origin relationships. European Journal of Marketing, 40 (5-6), 696-717.

15. Pilling, M. (2016). Handbook of Cluster Analysis. Journal of The Royal Statistical Society Series A-Statistics in Society, $179(4), 1130-1130$

16. Superbrands (2017). slovaksuperbrands.com. Retrieved from http://www.slovaksuperbrands.com/superbrands. php?k=4\&id=178\&ev=2015.

17. Svec, M., Olsovska, A., \& Mura, L. (2015). Protection of an "Average Consumer" in the Digital Society - European Context. In: proceedings of International Scientific Conference on Marketing Identity (273-282). Slovak republic: Smolenice.

18. Trindade, G., Dias, J.G., \& Ambrosio, J. (2017). Extracting clusters from aggregate panel data: A market segmentation study. Applied Mathematics and Computation, 296, 277-288

19. Trinh, G., Romaniuk, J., \& Tanusondjaja, A. (2016). Benchmarking buyer behaviour towards new brands. Marketing Letters, 27 (4), 743-752.

20. Voyer, B.G., Kastanakis, M.N., \& Rhode, A.K. (2017). Co-creating stakeholder and brand identities: A cross-cultural consumer perspective. Journal of Business Research, 70, 399-410.

Я. Кльестікова, JUDr., PhD., викладач кафедри економіки, факультет експлуатації та економіки транспорту і зв'язку, Жилінський університет (м. Жиліна, Словаччина);

К. Яноскова, PhD., викладач кафедри економіки, факультет експлуатації та економіки транспорту і зв'язку, Жилінський університет (м. Жиліна, Словаччина)

Брендинг з розумінням: як національний профіль споживача впливає на сприйняття цінності бренду

Практика показала, що неприйнятна модель брендингу може бути моделлю брендингу, яка раніше була дуже доречною на інших ринках або для іншого бренду. Під час застосування кластерного аналізу в країнах ОЕСР в контексті моделі соиіальних вимірів Хофстеда ми виявили, що причиною иього явища є значимість впливу національного соціокультурного просрілю споживачів на суб'єктивне сприйняття цінності бренду. На прикладі Словацької Республіки було підтверджено, що клієнти вважають більш цінними бренди, соціально-культурний профіль країни походження яких зближується з національним. Згодом ми визначили індивідуальні атрибути соціокультурного профрілю з джерелами індивідуального сприйняття цінності бренду.

Ключові слова: бренд, брендинг, цінність бренду, національний профіль споживача, культурні аспекти Хофрстеда, Словацька Республіка, країни ОЕСР.

Я. Кльестикова, JUDr., PhD., преподаватель кафедры экономики, факультет эксплуатации и экономики транспорта и связи, Жилинский университет (г. Жилина, Словакия);

K. Яноскова, $P h D$., преподаватель кафедры экономики, факультет эксплуатации и экономики транспорта и связи, Жилинский университет (г. Жилина, Словакия)

Брендинг с пониманием: как национальный профиль потребителя влияет на восприятие ценности бренда

Практика показала, что неприемлемая модель брендинга может быть моделью брендинга, которая ранее была очень уместной на других рынках или для другого бренда. При применении кластерного анализа в странах ОЭСР в контексте модели социальных измерений Хофстеда мы обнаружили, что причиной этого явления является значимость влияния национального социокультурного профиля потребителей на субъективное восприятие ценности бренда. На примере Словацкой Республики было подтверждено, что клиенты считают более ценными бренды, социально-культурный профиль страны происхождения которых сближается с национальным. Впоследствии мь определили индивидуальные атрибуты социокультурного профиля с источниками индивидуального восприятия ценности бренда.

Ключевые слова: бренд, брендинг, ценность бренда, национальный профиль потребителя, культурные аспекты Хофстеда, Словацкая Республика, страны ОЭСР.

Отримано 19.03.2017 p. 